DOI: $10.19195 / 0137-1134.115 .3$

\author{
ADAM RZETECKI \\ ORCID: 0000-0001-9480-228X \\ Uniwersytet im. Adama Mickiewicza w Poznaniu
}

\title{
TRANSPARENTNOŚĆ FINANSÓW PARTII POLITYCZNYCH A UTRATA PRAWA DO SUBWENCJI Z BUDŻETU PAŃSTWA
}

\begin{abstract}
Abstrakt: Partie polityczne odgrywają znaczną rolę we współczesnym systemie demokratycznym, ponieważ bez nich nie byłby możliwy pluralizm polityczny, stanowiący jedną z zasad nowoczesnego państwa. Jednak dla rządzących problem zawsze stanowiło zagwarantowanie im bezpieczeństwa finansowego. System finansowania partii politycznych w Polsce opiera się na zasadzie finansowania ich poprzez subwencje budżetowe, ponieważ w naszych warunkach politycznych wydaje się to najefektywniejszym rozwiązaniem. Finanse partii politycznych powinny być jednakże w pełni transparentne i podlegać kontroli społecznej ze względu na gospodarowanie przez nie środkami publicznymi. Możliwości utraty subwencji w Polsce są związane z jawnością finansowania. Sankcja pozbawienia prawa do otrzymywania dotacji przez partie polityczne stanowi dolegliwość wynikającą z naruszenia norm prawnych dotyczących sprawozdawczości finansowej partii politycznych na dany rok kalendarzowy.
\end{abstract}

Słowa kluczowe: partia polityczna, subwencje, jawność finansowania, utrata subwencji, Państwowa Komisja Wyborcza

\section{WPROWADZENIE}

Możliwość swobodnej działalności partii politycznych odgrywa istotną rolę w funkcjonowaniu ustroju demokratycznego, definiowanego jako ograniczanie władzy większości przez godność człowieka i jego prawa ${ }^{1}$. Nie oznacza to jednak, że obecność stronnictw w przestrzeni społecznej jest konieczna, abyśmy mogli stwierdzić, że państwo jest demokratyczne, ponieważ znane są przypadki, gdy w wyniku wyborów powszechnych władzę zdobywają osoby niezwiązane z jakąkolwiek partią polityczną, co jest widoczne w szczególności na poziomie samorządu terytorialnego ${ }^{2}$. Jednak bez tych ugrupowań, co obrazuje rzeczywistość wielu państw świata, nie byłby możliwy pluralizm polityczny, stanowiący fasadę współ-

1 W.F. Murphy, Constitutional Democracy, Baltimore 2007, s. 6.

2 B. Banaszak, Porównawcze prawo konstytucyjne współczesnych państw demokratycznych, Warszawa 2012, s. 227.

Przegląd Prawa i Administracji 115, 2018

(C) for this edition by CNS 
czesnego państwa demokratycznego. Warto zauważyć, że nawet Trybunał Konstytucyjny (dalej: TK) w jednym z wyroków stwierdził wprost, że partie „z powodu swej zdolności oddziaływania na kształtowanie polityki państwa stanowią element systemu politycznego"3. W związku z tym poglądy wyrażane chociażby przez R. Michelsa, jakoby te formy zrzeszania obywateli groziły „,partiokracją", w której partie stają się „matką rządów ludzi wybranych nad wyborcami”", nie powinny być uznawane za wystarczający powód do ograniczania swobody działalności wspomnianych bytów politycznych.

Zasadniczym problemem jest jednak kwestia finansowania działalności stronnictw. Gdyby bowiem przyjąć, że partie utrzymują się z pieniędzy otrzymywanych od sponsorów, mogłoby to stwarzać warunki do rozwoju korupcji i skutkować tym, że partia realizowałaby wytyczne swoich „darczyńców” w zamian za wsparcie materialne. Aby uniknąć zjawisk patologicznych w polskim życiu politycznym, główny ciężar finansowania partii został przeniesiony na budżet państwa, przy jednocześnie znacznym ograniczeniu możliwości zdobywania środków z innych źródeł, głównie od osób prawnych ${ }^{5}$. Jednocześnie wprowadzono wiele rozwiązań zmierzających do zapewnienia przejrzystości i jawności finansów partii politycznych, aby działania związane z pozyskiwaniem przez stronnictwa polityczne środków pieniężnych były zgodne z obowiązującym prawem. W przeciwnym razie istnieje możliwość pozbawienia partii, należnej w związku z osiągniętym wynikiem wyborczym, subwencji z budżetu państwa. Jest to utrudnienie zwłaszcza dla małych ugrupowań, które z przyczyn finansowych i organizacyjnych nie zawsze są w stanie należycie wywiązać się z nałożonych przez ustawodawcę obowiązków, co prowadzi do negatywnych konsekwencji w postaci utraty subwencji. Od momentu wprowadzenia zasady finansowania partii politycznych z budżetu coraz wyraźniej widać zatem nierówności finansowe, które wpływają na dostęp do aktywności politycznej ${ }^{6}$. Przeciwnicy subwencji państwowych sygnalizują, że uprzywilejowują one te partie, które znajdują się w strukturach władzy, a dyskryminują nowe ugrupowania ${ }^{7}$. Dowodzi to, że kwestia podziału środków z budżetu państwa przeznaczanych na subwencje oraz możliwości utraty tych środków w związku z drobnymi uchybieniami wymaga nieustannego dopracowywania celem zaspokojenia oczekiwań społecznych ${ }^{8}$.

3 Wyrok TK z 8 marca 2000 roku, Pp 1/99, OTK 2000/2/58.

4 G. Sartori, Teoria demokracji, przeł. P. Amsterdamski, D. Grinberg, Warszawa 1996, s. 222.

5 J. Zbieranek, Finansowanie partii politycznych w Polsce - czy i jakie zmiany?, http://www. batory.org.pl /upload/files/Programy\%20operacyjne/Finansowanie-partii-politycznych_streszczenie. pdf (dostęp: 20.12.2016).

${ }^{6}$ K. Sobolewska-Myślik, Partie i systemy partyjne na świecie, Warszawa 2004, s. 163.

7 Ibidem, s. 166.

8 T. Bichta, Struktura organizacyjna partii politycznych w Polsce po 1989 roku, Lublin 2010, s. 89-90. 


\section{ZASADY PRZYZNAWANIA PARTIOM POLITYCZNYM SUBWENCJI Z BUDŻETU PAŃSTWA}

Pozyskiwanie środków finansowych na działalność partii politycznych stanowi jedno $\mathrm{z}$ najistotniejszych zagadnień $\mathrm{w}$ zakresie poprawnego funkcjonowania partii politycznych. W związku z tym kluczowe jest określenie przez ustawodawcę precyzyjnych, a także uczciwych dla wszystkich zasad finansowania, w tym zapewnienie publicznej jawności pozyskiwania środków. Podstawowy akt prawny regulujący funkcjonowanie polskich partii politycznych w Polsce, czyli ustawa z 27 czerwca 1997 roku o partiach politycznych ${ }^{9}$, w art. od 23a do 41 zawiera liczne regulacje odnoszące się do problemu finansów oraz finansowania partii politycznych. Ustawa w sposób jednoznaczny określa katalog możliwych źródeł powstawania majątku ugrupowań ${ }^{10}$. Zdaniem części przedstawicieli literatury wspomniany katalog sposobów zdobywania majątku przez partie należy jednak uznać za przykładowy, a nie zamknięty ${ }^{11}$. Istotne znaczenie ma to, że partia polityczna nie może prowadzić działalności gospodarczej ${ }^{12}$. W konsekwencji możliwości zdobywania przez ugrupowania środków na prowadzenie działalności politycznej są w Polsce silnie limitowane.

Mając to na uwadze, ustawodawca postanowił zrekompensować tę niedogodność poprzez wprowadzenie systemu subwencji, które w Polsce należy traktować jako podstawowe źródło pozyskiwania środków na działalność partyjną ${ }^{13}$. „Subwencja” zgodnie z definicją słownikową rozumiana jest jako „bezzwrotna pomoc finansowa udzielona celem popierania określonej działalności"14. W świetle przepisów ustawy, chociaż majątek stronnictwa tworzą środki pozyskiwane zarówno ze źródeł prywatnych, jak i publicznych, to właśnie subwencje z budżetu państwa zajmują szczególne miejsce w systemie finansowania partii. Wynika to nie tylko z wysokości kwot, które dzięki subwencjom budżetowym otrzymują stronnictwa polityczne ${ }^{15}$, lecz także z tego, że można je uznać za regularny i gwarantowany dochód partii (po spełnieniu przewidzianych prawem warunków), w odróżnieniu chociażby od majątku powstającego ze składek członkowskich ${ }^{16}$. Wspomniane

9 Ustawa z dnia 27 czerwca 1997 roku o partiach politycznych, Dz.U. z 1997 r. Nr 98, poz. 604 z późn. zm.

${ }^{10}$ K. Skotnicki, Modele i źródta finansowania partii politycznych, „Przegląd Sejmowy” 2014, nr 1, s. 29-31.

11 M. Granat, A. Gorgol, J. Sobczak, Ustawa o partiach politycznych. Komentarz, red. M. Granat, Warszawa 2003, s. 87.

12 M. Dębska, Ustawa o partiach politycznych. Komentarz, Warszawa 2013, s. 54-58.

13 M. Münnich, Subwencja budżetowa dla partii politycznych, „Państwo i Prawo” 2013, nr 12, s. $60-64$.

14 Słownik języka polskiego, t. 3. R-Z, red. M. Szymczak, Warszawa 1998, s. 340.

15 J. Zawadzki, System finansowania partii politycznych $w$ Polsce - praktyka i kierunki rozwoju, ,Studia Ekonomiczne/Uniwersytet Ekonomiczny w Katowicach” 2013, nr 169, s. 219-220.

16 A. Ławniczak, Finansowanie partii politycznych, Warszawa 2001, s. 47-48. 
świadczenie przysługuje przez całą kadencję Sejmu ${ }^{17}$, a obejmuje partie, które startując samodzielnie w wyborach sejmowych, uzyskały w skali kraju przynajmniej 3\% poparcia na listy okręgowe (art. 28 ust. 1 pkt 1 u.p.p.). Ustawodawca promuje zatem stronnictwa, którym udało się przekonać do siebie przynajmniej niewielką część wyborców. Środki te mogą pomóc małym ugrupowaniom w skuteczniejszej walce $\mathrm{w}$ przyszłości o miejsce $\mathrm{w}$ parlamencie ${ }^{18}$. Subwencję dostanie również partia startująca w wyborach $\mathrm{w}$ ramach koalicji wyborczej, gdy koalicja ta uzyska minimum $6 \%$ ważnych głosów (art. 28 ust. 1 pkt 1 u.p.p.). Należy w tym miejscu wspomnieć, że w drugim przypadku zawiązanie koalicji wyborczej partii politycznych łączy się z koniecznością zawarcia umowy tworzącej koalicję, która pod rygorem nieważności musi być przedłożona Państwowej Komisji Wyborczej (dalej: PKW) celem jej rejestracji. Umowa powinna w sposób sztywny i niepodlegający zmianom określać proporcje, na podstawie których dzielona będzie pomiędzy partie ewentualna subwencja. Nieokreślenie warunków podziału subwencji w ten sposób powoduje utratę prawa do niej ${ }^{19}$.

Wysokość rocznej subwencji ustala się na zasadzie stopniowej dygresji ${ }^{20}$, proporcjonalnie do łącznej liczby ważnych głosów oddanych na listy okręgowe kandydatów na posłów startujących z ramienia danej partii albo koalicji wyborczej w rozbiciu na liczby głosów odpowiadające poszczególnym przedziałom określonym w procentach ${ }^{21}$. Kwotę należności oblicza się, stosująć równanie z art. 29 ust. 1 u.p.p.:

$$
\mathrm{S}=\mathrm{W}_{1} \times \mathrm{M}_{1}+\mathrm{W}_{2} \times \mathrm{M}_{2}+\mathrm{W}_{3} \times \mathrm{M}_{3}+\mathrm{W}_{4} \times \mathrm{M}_{4}+\mathrm{W}_{5} \times \mathrm{M}_{5}
$$

$\mathrm{S}$ - kwota rocznej subwencji,

W1-5 - liczby głosów kolejno obliczane dla każdego wiersza tabeli 1, podane odrębnie w wyniku rozbicia łącznej liczby głosów ważnych oddanych w skali kraju łącznie na listy okręgowe kandydatów na posłów danej partii politycznej albo koalicji wyborczej, odpowiednio do wyznaczonego w procentach przedziału, M1-5 - wysokość kwoty w złotych dla kolejnych wierszy tabeli 1.

17 K. Sobolewska-Myślik, op. cit., s. 165.

18 A. Lawniczak, op. cit., s. 159.

19 M. Dębska, op. cit., s. 68-69.

20 J.K. Sokołowski, K. Streb, Skład polityczny Sejmu w latach 1997-2007, [w:] Wybrane aspekty funkcjonowania Sejmu w latach 1997-2007, red. J.K. Sokołowski, K. Streb, Kraków 2008, s. 121.

21 T. Bichta, op. cit., s. 93. 
Tabela 1. Zestawienie liczby oddawanych głosów i kwot subwencji za każdy głos

\begin{tabular}{|l|l|l|}
\hline & $\begin{array}{l}\text { Głosy ważne oddane w całym kraju łącznie na } \\
\text { listy okręgowe kandydatów na posłów danej } \\
\text { partii politycznej albo koalicji wyborczej w roz- } \\
\text { biciu odpowiednio dla każdego przedziału }\end{array}$ & Wysokość kwoty za jeden głos (M) \\
\hline 1. & do $5 \%$ & 5 złotych 77 groszy \\
\hline 2. & powyżej $5 \%$ do $10 \%$ & 4 złote 61 groszy \\
\hline 3. & powyżej $10 \%$ do $20 \%$ & 4 złote 4 grosze \\
\hline 4. & powyżej $20 \%$ do $30 \%$ & 2 złote 31 groszy \\
\hline 5. & powyżej $30 \%$ & 87 groszy \\
\hline
\end{tabular}

Źródło: T. Bichta, op. cit., s. 93-94.

Subwencja, zgodnie z art. 29 ust. 2 u.p.p., wypłacana jest każdego roku w czterech równych ratach kwartalnych, za udzieleniem przez PKW potwierdzenia wniosku odnośnie do prawa i wysokości subwencji, złożonego przez organ reprezentujący partię w terminie do 31 marca każdego roku ${ }^{22}$. Należy podkreślić, że okres jej pobierania pokrywa się z latami kalendarzowymi, a nie dokładnie z czasem trwania kadencji sejmowej. Subwencja przysługuje od 1 stycznia roku następującego po tym, w którym miały miejsce wybory, ale za to wypłacana jest do końca roku, w którym zorganizowano kolejne wybory. W sytuacji skrócenia kadencji Sejmu prawo do subwencji wygasa z końcem kwartału zakończenia kadencji Sejmu (art. 32 u.p.p.).

\section{KONTROLA FINANSÓW PARTII POLITYCZNYCH}

\subsection{ZASADA JAWNOŚCI FINANSOWANIA PARTII POLITYCZNYCH}

Konstytucja RP z 1997 roku $^{23}$ w art. 11 ust. 2 ustanowiła zasadę jawności jako odnoszącą się do finansowania partii politycznych. Motywacją jej obecności jest chęć zapobiegania zjawiskom korupcyjnym, a także nielegalnemu finansowaniu stronnictw politycznych, na przykład przez przedstawicieli świata biznesu czy obcych państw. Z zasady jawności finansowania partii wynika wiele szczegółowych: jawność źródeł finansowania partii politycznej, jawność majątku, dofinansowania partii z budżetu, szczegółowość sprawozdań finansowych składanych przez stronnictwa oraz nadzór w odniesieniu do finansów ze strony organów państwa ${ }^{24}$. Obecność tego typu rozwiązania na gruncie ustawy zasadniczej ma na celu pod-

22 A. Sokala, B. Michalak, P. Uziębło, Leksykon prawa wyborczego i referendalnego oraz systemów wyborczych, Warszawa 2013, s. 42-43.

23 Konstytucja Rzeczypospolitej Polskiej z dnia 2 kwietnia 1997 roku, Dz.U. Nr 78, poz. 483 z późn. zm.

24 M. Chmaj, Wolność tworzenia i działania partii politycznych, Olsztyn 2006, s. 155.

Przegląd Prawa i Administracji 115, 2018

(C) for this edition by CNS 
kreślenie, że ustawodawca traktuje transparentność działalności stronnictw politycznych jako jeden z wymogów, który musi być spełniony, aby można mówić o istnieniu demokratycznego państwa prawa, oraz świadczy o dostrzeżeniu roli partii politycznej jako podmiotu oddziałującego bezpośrednio na stosunki społeczne oraz gospodarcze w państwie ${ }^{25}$.

Nadzór i kontrolę nad kwestiami związanymi z finansowaniem partii politycznych można podzielić na dwie płaszczyzny. Pierwsza ma charakter typowo formalny, a realizują ją powołane do tego instytucje, na przykład PKW, Najwyższa Izba Kontroli, Centralne Biuro Antykorupcyjne oraz Urząd Zamówień Publicznych. Narzędzie formalne stanowi obowiązek sprawozdań finansowych przesyłanych każdego roku PKW oraz ich badanie przez biegłych rewidentów ${ }^{26}$. Nieformalną płaszczyzną zaś jest na przykład działalność stowarzyszeń i fundacji analizujących finansowanie partii politycznych, mająca swoje konsekwencje w instytucji tak zwanych zastrzeżeń (art. 34a ust. 5 u.p.p.).

\subsection{INFORMACJA FINANSOWA O OTRZYMANEJ SUBWENCJI}

Artykuł 34 u.p.p. nakłada obowiązek ,,polegający na sporządzeniu corocznej informacji finansowej o otrzymanej subwencji oraz o poniesionych z subwencji wydatkach", co wynika z uznania stronnictw politycznych za beneficjentów subwencji budżetowych ${ }^{27}$. Środki finansowe muszą być wydatkowane w ściśle określony sposób. Partie sporządzają coroczną informację finansową o otrzymanej subwencji oraz o poniesionych z subwencji wydatkach według wzoru określonego w rozporządzeniu ministra właściwego do spraw finansów publicznych, którą przedkładają PKW do 31 marca następnego roku. Zakres wymaganych informacji został określony w $§ 2$ rozporządzenia Ministra Finansów z 18 lutego 2003 roku w sprawie informacji finansowej o otrzymanej subwencji oraz o poniesionych $\mathrm{z}$ subwencji wydatkach ${ }^{28}$ i obejmuje dane o wydatkach partii politycznej, to znaczy o kwotach przekazanych na Fundusz Ekspercki i Fundusz Wyborczy, jak również na cele statutowe, zwłaszcza na wynagrodzenia, ubezpieczenia społeczne oraz inne świadczenia, zużycie materiałów, energii, usługi obce (wśród nich korzystanie ze środków masowego przekazu) oraz podatki i opłaty. Ponadto informacja finansowa przedstawia informacje odnośnie do spłaconych kredytów bankowych wraz z odsetkami oraz tych wydatków, które poniesiono niezgodnie z przeznaczeniem określonym w art. 28 ust. 1 ustawy z 27 czerwca 1997 roku o partiach politycznych. Co więcej, w informacji powinny być zawarte dane dotyczące wydatków poniesionych z Funduszu Eksperckiego na ekspertyzy niezbędne

25 W. Sokolewicz, Komentarz do art. 11, [w:] Konstytucja Rzeczypospolitej Polskiej. Komentarz, red. L. Garlicki, Warszawa 2007, s. 46.

26 J. Zawadzki, op. cit., s. 220-221.

27 M. Dębska, op. cit., s. 81.

28 Rozporządzenie Ministra Finansów z 18 lutego 2003 roku w sprawie informacji finansowej o otrzymanej subwencji oraz o poniesionych z subwencji wydatkach, Dz.U. Nr 33, poz. 268. 
w działalności politycznej partii, działalność wydawniczo-edukacyjną oraz cele niezgodne z przeznaczeniem.

M. Walecki zauważa, że obecnie instytucja informacji finansowej ma liczne mankamenty, przez co nie można traktować jej jako w pełni rzetelnego źródła informacji, co przecież stanowi zamiar ustawodawcy ${ }^{29}$. W rzeczonym dokumencie bowiem partia deklaruje kategorie wydatków, na jakie przeznaczyła pieniądze z subwencji. Należy jednak spostrzec, że kategorie te są sformułowane w sposób ogólny, przez co nie dają możliwości należytego rozszyfrowania charakteru wydatków. W konsekwencji ugrupowania polityczne rozliczają się z subwencji na ogólnych formularzach, zawierających nieprecyzyjnie ujęte kategorie wydatków, za którymi przecież mogą się kryć najróżniejsze transakcje ${ }^{30}$. Jak zauważa M. Dębska ${ }^{31}$, informację należy przekazać wraz z opinią i raportem biegłego rewidenta, wybieranego przez PKW. Wyznaczenie biegłego rewidenta przez PKW ma zapewnić obiektywność i bezstronność, a przede wszystkim zapobiec próbom wpływania na rezultaty jego pracy przez osoby bezpośrednio zainteresowane. W siedzibie partii rewident ma wgląd $\mathrm{w}$ dokumenty związane $\mathrm{z}$ wydatkowaniem subwencji, na podstawie których sporządza raport oraz opinię. Zdaniem J. Zbieranka trudno jednak mówić o całkowitej skuteczności opisanej kontroli, ponieważ dotyczy ona zasadniczo kwestii rachunkowych, a nie merytorycznej strony wydatków ${ }^{32}$. Informację finansową PKW ogłasza w Dzienniku Urzędowym Rzeczypospolitej Polskiej „Monitor Polski” w terminie 14 dni od dnia jej złożenia (art. 34 ust. 5 u.p.p.). Wynika to z faktu, że wydatki partii politycznej, a zwłaszcza te związane z dysponowaniem pieniędzmi pochodzącymi z budżetu państwa, są sprawą publiczną. NSA w wyroku z dnia 18 grudnia 2014 roku kategorycznie stwierdził, że ,wydatki partii politycznej są sprawą publiczną, a informacja na ten temat podlega — co do zasady — udostępnieniu na zasadach i w trybie określonych w przepisach u.d.i.p." ${ }^{33}$.

\subsection{SPRAWOZDANIE O ŹRÓDŁACH POZYSKANIA ŚRODKÓW FINANSOWYCH}

Artykuł 38 ust. 1 u.p.p. nakłada na wszystkie partie bezwzględny obowiązek sprawozdawczy ${ }^{34}$, na który składa się coroczne złożenie „PKW, nie później niż do 31 marca każdego roku, sprawozdania o źródłach pozyskania środków finansowych, w tym o kredytach bankowych i warunkach ich uzyskania, oraz o wydatkach poniesionych ze środków Funduszu Wyborczego w poprzednim roku kalen-

29 M. Walecki, Pieniądz a polityka w Europie Środkowo-Wschodniej, [w:] Kulisy finansowania polityki, red. M. Walecki, Warszawa 2002, s. 47-82.

${ }^{30}$ J. Zbieranek, Subwencje z budżetu państwa dla partii politycznych. Jawność i kontrola, „Przegląd Sejmowy” 2010, nr 1, s. 198-202.

31 M. Dębska, op. cit., s. 82.

32 J. Zbieranek, Subwencje z budżetu..., s. 198-202.

33 Wyrok NSA z 18 grudnia 2014 roku, I OSK 687/14, LEX nr 1650433.

34 M. Dębska, Ustawa o partiach politycznych. Komentarz, https://sip.lex.pl/\#/komentarz/58744 0209/237649 (dostęp: 3.01.2017). 
darzowym". Sprawozdanie sporządza się na podstawie wzoru określonego przez rozporządzenie Ministra Finansów z 18 lutego 2003 roku w sprawie sprawozdania o źródłach pozyskania środków finansowych ${ }^{35}$.

Do sprawozdania obowiązkowo należy załączyć kopie (poświadczone przez odpowiednie osoby reprezentujące organy statutowe partii politycznej z podaniem imienia, nazwiska i stanowiska służbowego oraz opatrzone klauzulą „,za zgodność z oryginałem”) następujących dokumentów: 1) umów rachunków bankowych — bieżących i Funduszu Wyborczego; 2) wyciągów bankowych prowadzonych rachunków bankowych na ostatni dzień okresu sprawozdawczego oraz historii każdego rachunku; 3) umów kredytu bankowego; 4) umów i innych dokumentów dotyczących użyczenia posiadanych przez partię nieruchomości i lokali oraz 5) wyciągu z rachunku prowadzonego w biurze maklerskim potwierdzającego przychody z obrotu obligacjami Skarbu Państwa i bonami skarbowymi Skarbu Państwa ${ }^{36}$.

Warto zaznaczyć, że opisywany bezwzględny obowiązek sprawozdawczy odnosi się do wszystkich partii, także tych, które zostały wykreślone w ciągu poprzedniego roku kalendarzowego z ewidencji partii politycznych. Dowiódł tego SN postanowieniem z dnia 10 marca 2008 roku, w którym wykazał, że:

Wykreślenie partii politycznej, która uczestniczyła lub podjęła działania w celu uczestniczenia w wyborach parlamentarnych, z ewidencji partii politycznych prawomocnym postanowieniem Sądu nie ma wpływu na realizację przez partię obowiązku, o którym mowa w art. 38 ust. 1 i 3 ustawy z dnia 27 czerwca 1997 r. o partiach politycznych. Ponadto, w sytuacji, gdy partia wykreślona z ewidencji partii politycznych złoży Państwowej Komisji Wyborczej sprawozdanie, o którym mowa w art. 38 ust. 1 ustawy, postępowanie przed Państwową Komisją Wyborczą nie staje się bezprzedmiotowe tylko $\mathrm{z}$ tego powodu, że partia polityczna została wykreślona $\mathrm{z}$ rejestru prawomocnym orzeczeniem Sądu ${ }^{37}$.

Orzeczenie to podkreśla fundamentalną rolę sprawozdania o źródłach pozyskania środków finansowych przez partie polityczne dla przejrzystości finansów stronnictw politycznych, ponieważ wskazuje na bezwzględny obowiązek sprawozdawczy, którego nie można uniknąć, a którego dopełnienie jest koniecznością, nawet gdy partia już została wykreślona z ewidencji partii politycznych.

\section{PRZESŁANKI UTRATY SUBWENCJI BUDŻETOWEJ PRZEZ PARTIĘ POLITYCZNĄ}

Nałożone na partie obowiązki sporządzenia informacji finansowej, a także złożenia sprawozdania o źródłach pozyskania środków finansowych mają na celu przyczynienie się do zapewnienia transparentności funkcjonowania stronnictw politycznych w Polsce. Analizowanie partyjnych dokumentów przez wyspecja-

35 Rozporządzenie Ministra Finansów z 18 lutego 2003 roku w sprawie sprawozdania o źródłach pozyskania środków finansowych, Dz.U. Nr 33, poz. 269.

36 M. Dębska, Ustawa o partiach politycznych. Komentarz, https://sip.lex.pl/\#/komentarz/58744 0209/237649.

37 Postanowienie SN z 10 marca 2008 roku, III SK 25/07, OSNP 2009/11-12/164.

Przegląd Prawa i Administracji 115, 2018

(C) for this edition by CNS 
lizowane podmioty pozwala wykryć ewentualne uchybienia, ale przede wszystkim ma ono pełnić funkcję odstraszającą, albowiem świadomość nieuniknionej zewnętrznej kontroli działalności ugrupowania powinna zniechęcać do nieetycznych działań, które mogą wiązać się z korupcją. Ponadto jawność finansowania polityki, jak twierdzi S. Gebethner, stanowi niezbędny element realizacji postulatu państwa „przejrzystego"38. Należy zauważyć, że powinności związane z ujawnieniem działań partii, odnoszące się do kwestii finansowych, skłaniają je do zgodnego z prawem, racjonalnego gospodarowania środkami. Uchybienia w realizacji nałożonych przez ustawodawcę obowiązków będą bowiem skutkować utratą subwencji budżetowej, która stanowi główne źródło finansowania stronnictw liczących się na rodzimej scenie politycznej. Jej utrata, szczególnie w przypadku partii obecnych w Sejmie, może sparaliżować ich działalność.

\subsection{UTRATA SUBWENCJI W ZWIĄZKU Z UCHYBIENIAMI DOTYCZĄCYMI INFORMACJI FINANSOWEJ}

Jak wynika z art. 34a ust. 1 u.p.p., PKW od dnia złożenia corocznej informacji ma sześć miesięcy na dokonanie rzetelnej weryfikacji danych dotyczących przeznaczenia pieniędzy z subwencji. Może ona przyjąć informację bez zastrzeżeń albo ze wskazaniem uchybień oraz ją odrzucić. Dokonuje tego w drodze uchwa${ }^{3}{ }^{39}$. Negatywne konsekwencje ma dla stronnictwa odrzucenie informacji finansowej przez PKW, ponieważ oznacza to utratę subwencji budżetowej na rok. Ponadto partia polityczna traci prawo do niej, gdy nie złoży informacji w terminie określonym w art. 34 ust. 2 albo SN oddali skargę, o której mowa w art. 34b ust. 1 u.p.p. W przypadku zaistnienia jednej z powyższych przesłanek „PKW otrzymawszy wniosek o wypłacenie subwencji za dany rok, przekazuje go Ministrowi Finansów wraz z informacją o utracie przez partię prawa do otrzymywania subwencji. Wówczas Minister nie dokonuje wypłaty subwencji”40. Zgodnie z art. 34c ust. 2 u.p.p. utrata przez partię polityczną prawa do subwencji następuje w kolejnym roku kalendarzowym po roku, w którym wystąpiło zdarzenie stanowiące przesłankę utraty prawa do niej. Wynika z tego, że subwencja nie jest wypłacana w roku następującym po roku, którego miała dotyczyć informacja odrzucona albo niezłożona na czas.

Odrzucenie informacji, zgodnie $\mathrm{z}$ art. 34a ust. 1a u.p.p., następuje w przypadku stwierdzenia wykorzystania przez partię środków z subwencji na cele inne niż związane z jej działalnością statutową ${ }^{41}$. W razie wystąpienia wątpliwości odno-

38 J. Łapiński, Kartel wyborczy partii politycznych (uwagi na temat systemu finansowania polityki w Polsce), [w:] Konstytucja, ustrój polityczny, system organów państwowych. Prace ofiarowane Profesorowi Marianowi Grzybowskiemu, red. S. Bożyk, A. Jamróz, Białystok 2010, s. 306.

39 M. Dębska, Ustawa o partiach politycznych. Komentarz, s. 84.

40 M. Dębska, Ustawa o partiach politycznych. Komentarz, https://sip.lex.pl/\#/komentarz/58744 0209/237649.

41 A. Sokala, B. Michalak, P. Uziębło, op. cit., s. 44.

Przegląd Prawa i Administracji 115, 2018

(C) for this edition by CNS 
śnie do rzetelności informacji PKW może zwrócić się do partii politycznej o usunięcie wad informacji czy też o udzielenie wyjaśnień w określonym terminie ${ }^{42}$. Obecnie opinia biegłego rewidenta nie przesądza o przyjęciu albo odrzuceniu informacji finansowej, a jej znaczenie sprowadza się głównie do roli pomocniczej. Ma ona za zadanie ułatwić podjęcie ostatecznej decyzji, ale negatywna opinia biegłego rewidenta nie determinuje już kierunku rozstrzygnięć PKW. Zmiana ta, dokonana ustawą z 26 lipca 2002 roku o zmianie ustawy — Ordynacja wyborcza do rad gmin, rad powiatów i sejmików województw oraz o zmianie niektórych innych ustaw ${ }^{43}$, została oceniona pozytywnie w środowisku prawniczym ${ }^{44}$.

Kolejny przypadek powodujący utratę prawa do subwencji, a więc niezłożenie informacji w określonym terminie, sprowadza się do tego, że stronnictwo polityczne traci subwencję z budżetu państwa, jeżeli informacja finansowa za rok kalendarzowy nie została przekazana PKW do 31 marca następnego roku. Należy uznać, że termin ten, podobnie jak termin wyznaczony przez art. 38 ust. 1 u.p.p., ma charakter „terminu ustawowego”. SN postanowieniem w składzie siedmiu sędziów z 3 października 2002 roku stwierdził, że jego przekroczenie powoduje odrzucenie sprawozdania ${ }^{45}$. Tę samą zasadę należy odnieść również do informacji finansowej, albowiem w obu przypadkach ustawodawca w sposób jednoznaczny wyznacza termin ostateczny do wypełnienia obowiązków określonych w ustawie oraz wskazuje negatywne konsekwencji wynikające z jego niedochowania.

Trzecia możliwość utraty subwencji budżetowej odnosi się do przypadku oddalenia przez SN skargi, o której mowa w art. 34b ust. 1 u.p.p. Partia polityczna, która nie zgadza się z odrzuceniem przez PKW swojej informacji finansowej, zgodnie $\mathrm{z}$ art. 34b ust. 1 ma możliwość „,w terminie 7 dni od dnia doręczenia postanowienia o odrzuceniu informacji wnieść do SN skargę na postanowienie PKW w przedmiocie odrzucenia informacji”. Uprawnienie do złożenia skargi stanowi przejaw prawa do sądu, wyrażonego w art. 45 Konstytucji RP. SN rozpatruje skargę partii politycznej, wydając w terminie 60 dni od dnia doręczenia skargi orzeczenie w sprawie. Należy zaznaczyć, że jest to termin instrukcyjny, a zatem jego upływ nie pozbawia sądu możliwości rozstrzygnięcia sprawy ${ }^{46}$. Orzeczenie SN jest ostateczne i nie przysługuje od niego odwołanie. W konsekwencji SN może w swoim postanowieniu oddalić bądź uznać skargę za zasadną. Uznanie skargi za zasadną zobowiązuje PKW do niezwłocznego wydania postanowienia o przyjęciu informacji (art. 34b ust. 3-4 u.p.p.).

42 M. Dębska, Ustawa o partiach politycznych. Komentarz, s. 85.

43 Ustawa z 26 lipca 2002 roku o zmianie ustawy — Ordynacja wyborcza do rad gmin, rad powiatów i sejmików województw oraz o zmianie niektórych innych ustaw, Dz.U. Nr 127, poz. 1089.

44 A. Gorgol, [w:] Ustawa o partiach politycznych. Komentarz, red. M. Granat..., s. 143.

45 Postanowienie SN w składzie 7 sędziów z 3 października 2002 roku, III SW 24/02, LEX nr 359203.

46 M. Dębska, Ustawa o partiach politycznych. Komentarz, s. 86-87. 


\subsection{UTRATA PRAWA DO SUBWENCJI W ZWIĄZKU Z UCHYBIENIAMI DOTYCZĄCYMI SPRAWOZDANIA O ŹRÓDŁACH POZYSKANIA ŚRODKÓW FINANSOWYCH}

$\mathrm{Z}$ art. 38a ust. 1 u.p.p. wynika, że PKW ma sześć miesięcy od dnia złożenia sprawozdania na jego rozpatrzenie. Efektem rozpatrzeń może być przyjęcie sprawozdania bez zastrzeżeń, przyjęcie ze wskazaniem uchybień albo całkowite jego odrzucenie ${ }^{47}$. Artykuł 38d u.p.p. wskazuje dwa przypadki, w których stronnictwo polityczne traci prawo do otrzymywania subwencji: ,1) prawomocne odrzucenie sprawozdania finansowego przez PKW; 2) wydanie przez SN postanowienia, w którym oddala skargę w przedmiocie uchwały PKW o odrzuceniu sprawozdania"48.

W wypadku ziszczenia się choć jednej z tych przesłanek partia polityczna traci prawo do otrzymania subwencji w następnych trzech latach, w których jest do tego uprawniona. Termin natomiast liczy się od początku kwartału następującego po kwartale, w którym odrzucono sprawozdanie, a w razie złożenia skargi na postanowienie o odrzuceniu sprawozdania — od początku kwartału następującego po kwartale, w którym nastąpiło oddalenie skargi przez SN (art. 38d u.p.p.). Jak widać, utrata subwencji w związku z uchybieniami odnoszącymi się do sprawozdania o źródłach pozyskania środków finansowych jest karą dotkliwą, mogącą całkowicie zachwiać finansami partii, a w rezultacie uniemożliwić prowadzenie przez nią działalności politycznej. Jej dolegliwość dobitnie świadczy, że ustawodawca nie toleruje zdarzeń będących przesłankami umożliwiającymi odrzucenie sprawozdania finansowego przez PKW. Stanowią one bowiem zdecydowane naruszenie przepisów ustawy oraz stoją w sprzeczności z zasadą jawności i transparentności funkcjonowania partii, stanowiących fundament działania stronnictw politycznych w demokratycznym państwie prawa. Wspomniane przesłanki odrzucenia sprawozdania zostały ujęte w katalogu ustawowym (art. 38a ust. 2 i 3 u.p.p.):

Odrzucenie sprawozdania następuje w przypadku:

1) prowadzenia przez partię polityczną działalności gospodarczej (jest to sprzeczne z art. 24 ust. 3 u.p.p.; TK w wyroku z dnia 14 grudnia 2004 r., K 25/03 wskazał, iż brak możliwości prowadzenia działalności gospodarczej przez partie polityczne jest rekompensowany przyznaniem subwencji budżetowej ${ }^{49}$ );

2) pozyskiwania środków finansowych ze zbiórek publicznych;

3) gromadzenia środków finansowych poza rachunkiem bankowym z naruszeniem przepisów art. 24 ust. 8 (SN w postanowieniu z dnia 3 października 2002 r., III SW 18/02, stwierdził, że: ,Jedną z istotnych gwarancji mających zapewnić skuteczną realizację zasady jawności źródeł finansowania partii politycznych (art. 23a ustawy o partiach politycznych), jest wprowadzony art. 24 ust. 8 ustawy

47 S. Ślusarczyk, Finansowanie partii politycznych w Polsce - ewolucja i problemy praktyki w świetle orzecznictwa, [w:] Partie polityczne: permanentne problemy. Studia z zakresu funkcjonowania systemu politycznego, red. J. Kornaś, Kielce 2005, s. 228.

48 M. Dębska, Ustawa o partiach politycznych. Komentarz, https://sip.lex.pl/\#/komentarz/58744 0209/237649.

49 Wyrok TK z 14 grudnia 2004 roku, K 25/03, OTK-A 2004, nr 11, poz. 116. 
o partiach politycznych w sposób jednoznaczny i kategoryczny zarazem obowiązek, w myśl którego: „partia polityczna może gromadzić środki finansowe jedynie na rachunkach bankowych”50);

4) przyjmowania lub pozyskiwania środków finansowych $z$ innych źródeł niedozwolonych (np. anonimowej darowizny, ponieważ SN postanowieniem z dnia 5 listopada 2014 r., III SW 72/14, stwierdził, iż ,przyjęcie przez partię wpłaty o charakterze anonimowym z nieudokumentowanych źródeł stanowi naruszenie tego przepisu — art. 25 ust. 1 ustawy z 1997 r. o partiach politycznych — i w konsekwencji na podstawie art. 38a ust. 2 pkt 4 ustawy prowadzi do odrzucenia sprawozdania finansowego partii" ${ }^{\prime 1}$ );

5) gromadzenia lub dokonywania wydatków na kampanie wyborcze z pominięciem Funduszu Wyborczego;

6) gromadzenia środków finansowych Funduszu Wyborczego poza oddzielnym rachunkiem bankowym z naruszeniem przepisu art. 36 ust. 3;

7) przyjmowania wartości niepieniężnych z naruszeniem przepisów art. 25 ust. 4a.

3. Odrzucenie sprawozdania następuje również w przypadku poręczenia kredytu z naruszeniem przepisów art. 25a, a także dokonania czynności skutkującej zmniejszeniem wartości zobowiązań partii politycznej przez inną osobę aniżeli wymieniona w art. 25 ust. 1 i art. 25a ust. 1 lub dokonanej z naruszeniem limitu wpłat, o którym mowa w art. 25 ust. 4.

W przypadku odrzucenia przez PKW sprawozdania partia polityczna może, $\mathrm{w}$ terminie siedmiu dni od dnia doręczenia postanowienia o odrzuceniu sprawozdania, wnieść skargę na postanowienie PKW w sprawie odrzucenia sprawozdania do SN, który w terminie 60 dni od dnia doręczenia skargi wydaje orzeczenie w rzeczonej sprawie (art. 38b u.p.p.). Od orzeczenia sądu nie przysługuje już jednak żaden środek prawny. Uznanie przez SN skargi stronnictwa za zasadne skutkuje niezwłocznym wydaniem przez PKW postanowienia o przyjęciu sprawozdania. Oddalenie skargi natomiast wywołuje negatywne dla partii politycznej skutki w postaci utraty subwencji z budżetu w związku z art. 38d u.p.p.

\section{PODSUMOWANIE}

Finanse polskich partii politycznych — zarówno tych największych, jak i znajdujących się na granicy progu wyborczego - opierają się głównie na subwencjach z budżetu państwa. Środki, jakie stronnictwa mogą zyskać w ten sposób, są tak znaczne, że pozostałe metody finansowania partii nie byłby w stanie zrekompensować ewentualnej ich utraty. Postulaty zniesienia subwencji dla partii politycznych należy zatem traktować jako nierealne, tym bardziej że ten sposób finansowania partii ze środków publicznych jest praktyką obecną w prawie wszystkich państwach Unii Europejskiej ${ }^{52}$.

50 Postanowienie SN z 3 października 2002 roku, III SW 18/02, LEX nr 1169642.

51 Postanowienie SN z 5 listopada 2014 roku, III SW 72/14, LEX nr 1738534.

52 P. Krygiel, Powrót do debaty nad znajdujacym się w Sejmie projektem likwidacji finansowania partii politycznych z budżetu byłby ewenementem na skalę Unii Europejskiej, http://www. sobieski.org.pl/komentarz-is-161/ (dostęp: 1.01.2017).

Przegląd Prawa i Administracji 115, 2018

(C) for this edition by CNS 
Wprowadzone przez ustawę o partiach politycznych obowiązki sprawozdawczo-informacyjne, nakazujące partiom każdego roku przygotowywać informacje finansowe czy sprawozdania o źródłach pozyskania środków finansowych, znacząco przyczyniają się do zwiększenia jawności finansowania stronnictw politycznych, co jest szczególnie ważne dla poprawnego funkcjonowania demokratycznego państwa. Analiza dokumentów dotyczących finansów partii przez wyspecjalizowane podmioty służy nie tylko wykryciu uchybień, lecz przede wszystkim przyczynia się do zmiany kultury politycznej i modyfikacji myślenia o roli ugrupowań politycznych w życiu społecznym. Powinności związane z ujawnieniem działań partii skłaniają je do zgodnego z prawem, racjonalnego gospodarowania środkami. Ryzyko utraty subwencji budżetowej w związku z nieprzestrzeganiem przepisów ustawy skłania stronnictwa polityczne do większej troski o racjonalne gospodarowanie środkami zgromadzonymi na partyjnych rachunkach.

Warto przypomnieć, że raport GRECO (Grupa Państw Przeciwko Korupcji) z 2008 roku $^{53}$ pozytywnie ocenił polskie rozwiązania, sugerując jednak konieczność pewnych udoskonaleń, na przykład bardziej szczegółowej kontroli wydatków partii politycznych przez PKW, w tym konieczność większej weryfikacji danych, a także ułatwienie dostępu do informacji o wykorzystaniu środków przez partie dla przedstawicieli opinii publicznej.

\section{BIBLIOGRAFIA}

Banaszak B., Porównawcze prawo konstytucyjne współczesnych państw demokratycznych, Warszawa 2012.

Bichta T., Struktura organizacyjna partii politycznych w Polsce po 1989 roku, Lublin 2010.

Chmaj M., Wolność tworzenia i działania partii politycznych, Olsztyn 2006.

Dębska M., Ustawa o partiach politycznych. Komentarz, Warszawa 2013.

Gorgol A., [w:] Ustawa o partiach politycznych. Komentarz, red. M. Granat, Warszawa 2003.

Granat M., Gorgol A., Sobczak J., Ustawa o partiach politycznych. Komentarz, red. M. Granat, Warszawa 2003.

Łapiński J., Kartel wyborczy partii politycznych (uwagi na temat systemu finansowania polityki $w$ Polsce, [w:] Konstytucja, ustrój polityczny, system organów państwowych. Prace ofiarowane Profesorowi Marianowi Grzybowskiemu, red. S. Bożyk, A. Jamróz, Białystok 2010.

Ławniczak A., Finansowanie partii politycznych, Warszawa 2001.

Murphy W.F., Constitutional Democracy, Baltimore 2007.

Münnich M., Subwencja budżetowa dla partii politycznych, „Państwo i Prawo” 2013, nr 12.

Sartori G., Teoria demokracji, Warszawa 1996.

Skotnicki K., Modele i źródta finansowania partii politycznych, „Przegląd Sejmowy” 2014, nr 1.

Stownik języka polskiego PWN, t. 3. R-Z, red. M. Szymczak, Warszawa 1998.

Sobolewska-Myślik K., Partie i systemy partyjne na świecie, Warszawa 2004.

Sokala A., Michalak B., Uziębło P., Leksykon prawa wyborczego i referendalnego oraz systemów wyborczych, Warszawa 2013.

53 Ibidem.

Przegląd Prawa i Administracji 115, 2018

(C) for this edition by CNS 
Sokolewicz W., Komentarz do art. 11, [w:] Konstytucja Rzeczypospolitej Polskiej. Komentarz, red. L. Garlicki, Warszawa 2007.

Sokołowski J.K., Streb K., Skład polityczny Sejmu w latach 1997-2007, [w:] Wybrane aspekty funkcjonowania Sejmu w latach 1997-2007, red. J.K. Sokołowski, K. Streb, Kraków 2008.

Ślusarczyk S., Finansowanie partii politycznych w Polsce - ewolucja i problemy praktyki w świetle orzecznictwa, [w:] Partie polityczne: permanentne problemy. Studia z zakresu funkcjonowania systemu politycznego, red. J. Kornaś, Kielce 2005.

Walecki M., Pieniądz a polityka w Europie Środkowo-Wschodniej, [w:] Kulisy finansowania polityki, red. M. Walecki, Warszawa 2002.

Zawadzki J., System finansowania partii politycznych w Polsce - praktyka i kierunki rozwoju, „Studia Ekonomiczne/Uniwersytet Ekonomiczny w Katowicach” 2013, nr 169.

Zbieranek J., Subwencje z budżetu państwa dla partii politycznych. Jawność i kontrola, „Przegląd Sejmowy" 2010, nr 1.

\section{AKTY PRAWNE}

Konstytucja Rzeczypospolitej Polskiej z dnia 2 kwietnia 1997 roku, Dz.U. z 1997 r. Nr 78, poz. 483. Rozporządzenie Ministra Finansów z 18 lutego 2003 roku w sprawie informacji finansowej o otrzymanej subwencji oraz o poniesionych z subwencji wydatkach, Dz.U. Nr 33, poz. 268.

Rozporządzenie Ministra Finansów z 18 lutego 2003 roku w sprawie sprawozdania o źródłach pozyskania środków finansowych, Dz.U. Nr 33, poz. 269.

Ustawa z 27 czerwca 1997 roku o partiach politycznych, Dz.U. z 2011 r. Nr 155, poz. 924.

Ustawa z 26 lipca 2002 roku o zmianie ustawy - Ordynacja wyborcza do rad gmin, rad powiatów i sejmików województw oraz o zmianie niektórych innych ustaw, Dz.U. Nr 127, poz. 1089.

\section{ORZECZNICTWO}

Postanowienie SN z 3 października 2002 roku, III SW 18/02, LEX nr 1169642.

Postanowienie SN w składzie 7 sędziów z 3 października 2002 roku, III SW 24/02, LEX nr 359203.

Postanowienie SN z 10 marca 2008 roku, III SK 25/07, OSNP 2009/11-12/164.

Postanowienie SN z 5 listopada 2014 roku, III SW 72/14, LEX nr 1738534.

Wyrok NSA z 18 grudnia 2014 roku, I OSK 687/14, LEX nr 1650433.

Wyrok TK z 8 marca 2000 roku, Pp 1/99, OTK 2000/2/58.

Wyrok TK z 14 grudnia 2004 roku, K 25/03, OTK-A 2004/11/116.

\section{ŹRÓDŁA INTERNETOWE}

Dębska M., Ustawa o partiach politycznych. Komentarz, https://sip.lex.pl/\#/komentarz/587440209/ 237649.

Krygiel P., Powrót do debaty nad znajdującym się w Sejmie projektem likwidacji finansowania partii politycznych z budżetu bytby ewenementem na skale Unii Europejskiej, http://www.sobieski. org.pl/komentarz-is-161/.

Zbieranek J., Finansowanie partii politycznych w Polsce - czy i jakie zmiany?, http://www.batory.org. $\mathrm{pl} /$ upload/files/Programy\%20operacyjne/Finansowanie-partii-politycznych_streszczenie.pdf. 


\title{
FINANCIAL TRANSPARENCY OF POLITICAL PARTIES AND THE LOSS OF STATE SUBSIDIES
}

\begin{abstract}
Summary
Political parties play an important role in the contemporary democratic system. However, guaranteeing their financial safety has always been a problem for the authorities. The system of financing political parties in Poland is based on the principle of budgetary subsidy because in our political conditions, subsidies seem to be the most effective solution. Thus, the finances of political parties should be fully transparent and subject to public control because of spending budgetary resources. In Poland, there exist certain circumstances which can lead to the loss of subsidies, which are connected with the financial transparency. The sanction of deprivation of the right to receive subsidies by political parties constitutes a challenge resulting from the violation of legal standards concerning financial reporting of political parties for the given calendar year.
\end{abstract}

Keywords: political party, subsidies, transparency of finance, loss of subsidy, The National Election Commission 